\title{
Influence of Planting Dates and Temperature on Plant Growth, Flowering and Fruiting of Strawberry in Agro Climatic Condition of Bihar, India
}

\author{
Kanchan Bhamini ${ }^{1}$, Ruby Rani ${ }^{1}$, Md. Abu Nayyer ${ }^{1 *}$, Md. Feza Ahmad ${ }^{1}$ and Afzal Ahmed ${ }^{2}$ \\ ${ }^{1}$ Department of Horticulture, Fruit and Fruit Technology, Bihar Agricultural University Sabour \\ Bhagalpur, Bihar-813 210, India \\ ${ }^{2}$ Department of Soil Science and Agricultural Chemistry, Bihar Agricultural University Sabour \\ Bhagalpur, Bihar-813 210, India \\ *Corresponding author
}

\begin{tabular}{|c|c|}
\hline & A B S T R A C T \\
\hline $\begin{array}{l}\text { Ke y w o r d s } \\
\text { Temperature, } \\
\text { Strawberry, } \\
\text { Plant growth, } \\
\text { Flowering, Fruiting }\end{array}$ & $\begin{array}{l}\text { The present experiment was conducted to study the influence of temperature on plant } \\
\text { growth, flowering and fruiting of strawberry under agro-climate of Bihar. The experiment } \\
\text { was laid out in split plot design with four different planting dates viz. } 15^{\text {th }} \text { October, } 1^{\text {st }} \\
\text { November, } 15 \text { th November and } 1^{\text {st }} \text { December as the main plot and three varieties like } \\
\text { Sweet Charlie, Festival, and Winter Dawn under sub plot with three replications. The } \\
\text { maximum plant growth in terms of plant height }(32.15 \mathrm{~cm}) \text {, plant spread }(30.53 \mathrm{~cm}) \text { and }\end{array}$ \\
\hline Article Info & growth was noted in Sweet Charlie at $1^{\text {st }}$ December planting a similar trend of result was \\
\hline $\begin{array}{l}\text { Accepted: } \\
28 \text { August } 2017 \\
\text { Available Online: } \\
\text { 10 September } 2017\end{array}$ & $\begin{array}{l}\text { recorded pertaining to flower and fruit set behavior. Variety Winter Dawn was the earliest } \\
\text { to flower in } 15^{\text {th }} \text { October planting. As per data pertaining to the first fruit initiation and } \\
\text { fruiting period was also noted in variety Winter Dawn }\left(7^{\text {th }} \text { November) in the } 15^{\text {th }} \text { October }\right. \\
\text { planting during the cropping season. Thus the planting time from } 15^{\text {th }} \text { October to } 1^{\text {st }} \\
\text { November was found ideal for the planting of strawberry in Bihar. }\end{array}$ \\
\hline
\end{tabular}

\section{Introduction}

Strawberry (Fragaria $x$ ananassa D.) has unique, attractive, very pleasant taste and flavor and is considered as most popular fruit. In India, it is planted at different times of the years in a specific area for their commercial cultivation. Consumers mainly purchase strawberries for an enjoyable eating experience.

The components of quality can be sensory and nutritional. Media reports have indicated increasing consumer dissatisfaction with the flavour and inconsistent quality of strawberries (Sturm et al., 2003).
Strawberries are a good source of ascorbic acid (vitamin C) which is a very important nutrient, being essential. Cultivation of strawberry is greatly influenced by specified regional adaptation due to critical photoperiod and temperature requirement. Temperature plays an important role in the successful cultivation of strawberry. Temperatures have the considerable effects on growth, flowering and fruiting behavior of different varieties of strawberry. In sub-tropical climate, the rate of flower development increases with high temperature $\left(25^{\circ} \mathrm{C}\right)$ in all commercial varieties of strawberry. 
Strawberry is a non-climacteric temperate fruit crop. Being highly remunerative, short duration nature, high return and wider soil adaptability, it is now most popular in subtropical climatic condition also. In cold climate, frost damage and winter injury are the major constraints for their successful cultivation.

For successful strawberry cultivation, temperature plays an important role in the flowering and fruiting behavior of different strawberry cultivars. It is considered as one of the most important factors for profitable cultivation of strawberry. So, the effect of different temperature as affected by different planting time on vegetative growth, flowering, fruiting and harvesting period of strawberry cultivars were studied in field condition of the subtropical agro climate of Bihar under Indo Gangetic plain of India. However, strawberry can be planted at different times of the year depending on variety, location, and climate (Galleta and Bringhurst, 1990).

Both planting time and varieties have been recognized to influence fruit production as well as the quality of strawberry. In India, strawberry is usually planted in the second fortnight of October with traditional methods, which restrict the fruit availability for a very short period of one and a half month (Singh et al., 2007). The availability of fruit in MarchApril month reduces the profit of farmers considerably. However, staggered planting from mid-September to mid-October at the weekly/bi-weekly interval is quite remunerative for a longer period of availability of fruits (January to April) (Fig. 1).

Therefore, the present experiments were conducted to study the effect of temperature on plant growth, flowering and fruiting behavior in different strawberry cultivars under Indo Gangetic plain of India.

\section{Material and Methods}

The experiment was performed at the Horticulture Garden of Bihar Agricultural University, Sabour, Bhagalpur (Bihar), India. The design of the present experiment was laid out in a split plot with planting dates as main plot and varieties under sub-plot with three replications. The three varieties were taken under this experiment i.e. Sweet Charlie $\left(\mathrm{V}_{1}\right)$, Festival $\left(\mathrm{V}_{2}\right)$ and Winter Dawn $\left(\mathrm{V}_{3}\right)$ with four different planting dates i.e. $15^{\text {th }}$ October $\left(D_{1}\right)$, $1^{\text {st }}$ November $\left(D_{2}\right), 15^{\text {th }}$ November $\left(D_{3}\right)$ and $1^{\text {st }}$ December $\left(D_{4}\right)$ respectively. In this research, those planting materials were used which were prepared from mother plant maintained in the nursery of horticulture garden and maintained in the plug tray.

Plants with 4-5 leaves that were uniform in age and vigour were selected for planting. Plants were transplanted on properly leveled 1 $\mathrm{m}$ wide and $35 \mathrm{~cm}$ raised bed on all four planting dates at a planting distance of $20 \mathrm{~cm}$ (plant to plant) $\times 30 \mathrm{~cm}$ (row to row) with a plot size of about $3 \mathrm{~m}^{2}$ which accommodates 30 plants per plot. The distances between the plots were $50 \mathrm{~cm}$ which accommodating 30 plants per plot. The distance between the plots was $50 \mathrm{~cm}$. Under this experiment, ten plants were randomly selected in each treatment and tagged for taking observations on plant growth development, flowering, and fruiting behavior.

The maximum and minimum temperature, relative humidity at 8 am and $2 \mathrm{pm}$ of daily weather data were taken from university observatory from $1^{\text {st }}$ planting date i.e., $15^{\text {th }}$ October till final harvest stage. The plant height of randomly selected tagged plants was measured with the help of meter scale in centimeter from base to tip of the highest leaf of the plant and spread were taken in N-S and E-W direction separately with the help of 
meter scale at 20 days interval. After the completion of harvesting period, the total number of leaves was counted from tagged plants in each replication at 10 days interval and also expressed as an average number of leaves per plant.

Initiation of flowering was taken after planting in tagged plants started to flower and initiation of fruit set was counted from planting in tagged plants started to fruit set. The number of fruits per plant was observed in selected tagged plant at 10 days interval. All the fruits from first fruit set to the last fruiting were noted in each tagged plant and average of each plant was taken as a number of fruits per plant. Fruits that were free from any pest and disease infection and bruising with the weight of fruit more than $8 \mathrm{~g}$ were considered as marketable fruit and expressed as percentage.

\section{Results and Discussion}

\section{Plant growth behavior}

In the present study, data reflected that the plant growth parameters like plant height, plant spread and number of leaves per plant at 20 days interval were affected by different dates of planting and varieties of strawberry at different average temperature (Figs. 2 and 3). Data revealed that variety Winter Dawn exhibited maximum plant height $(32.15 \mathrm{~cm})$, and spread $(30.53 \mathrm{~cm})$ which was planted on $15^{\text {th }}$ October. Varietal differences in plant growth in terms of plant spread and height were also noted by Singh et al., (2008) in Meghalaya. It reduced with subsequent planting date and minimum plant growth was noted in variety Sweet Charlie under $1^{\text {st }}$ December planting. Weather parameters like temperature and relative humidity prevailing at the time of planting and early growth stage might have played significant role in plant growth as the average maximum $\left(30.3^{\circ} \mathrm{C}\right)$ and minimum $\left(19.1{ }^{0} \mathrm{C}\right)$ temperature was high during $15^{\text {th }}-31^{\text {st }}$ October (Table 1). The higher prevailing temperature at the planting time and subsequent period of plant growth in $15^{\text {th }}$ October planting seems to be conducive for growth and development of strawberry in all three varieties. Similar work has been noted by Singh and Asrey (2005), Sharma and Sharma (2004) and Hassan et al., (2000) in different climatic conditions in strawberry. The environmental condition especially favourable temperature was helpful in retaining more vegetative growth as reported by Palha et al., (2012). So, the prevalent climatic conditions at the time of planting subsequent period of plant growth might have affected the vegetative growth of strawberry plants. Similar results have been reported by Lal and Rao (2010).

Hence, the faster pace of plant growth was noted at a higher temperature. Likewise, variety Winter Dawn exhibited a maximum number of leaves per plant (48.21) at 20 days interval in $15^{\text {th }}$ October planting as the average maximum $\left(29^{\circ} \mathrm{C}\right)$ and minimum $\left(16.1^{\circ} \mathrm{C}\right)$ temperature. Reports of Palha et al., (2012) was also in consonance with the same findings who noted the variation in leaf production in strawberry with different planting date.

\section{Flowering and fruiting behaviour}

Planting time had greatly influence on flowering and fruiting behavior on strawberry cultivars. Variety Winter Dawn took earliest initiation of flowering ( $27^{\text {th }}$ Nov.) in $15^{\text {th }}$ October planting and their end of flower initiation was noted in $17^{\text {th }}$ March. Delay in initiation of flowering was noted in variety Sweet Charlie under $1^{\text {st }}$ December planting with their end of flowering was $12^{\text {th }}$ March. This might be possible that plant of midOctober planting have sufficient time for proper growth up to mid-December, which might also have advanced the flowering and fruiting (Tables 2 and 3; Figs 3 and 4). 
Table.1 Average weather data during initial stage of plant growth

\begin{tabular}{|c|c|c|c|c|}
\hline \multirow{2}{*}{ Duration } & \multicolumn{2}{|c|}{ Temperature $\left.\mathbf{(}^{\mathbf{0}} \mathbf{C}\right)$} & \multicolumn{2}{c|}{ Relative Humidity (\%) } \\
\cline { 2 - 5 } & Maximum & Minimum & Maximum & Minimum \\
\hline $15^{\text {th }}$ Oct. to $31^{\text {st }}$ Oct. & 30.3 & 19.1 & 90.1 & 65.6 \\
\hline $1^{\text {st }}$ Nov. to $15^{\text {th }}$ Nov. & 29.2 & 16.2 & 90.7 & 61.2 \\
\hline $16^{\text {th }}$ Nov. to $30^{\text {th }}$ Nov. & 28.2 & 14.0 & 88.3 & 61.4 \\
\hline $1^{\text {st }}$ Dec. to $15^{\text {th }}$ Dec. & 24.9 & 13.0 & 95.9 & 67.5 \\
\hline
\end{tabular}

Table.2 Effect of date of planting on initiation of flowering in different varieties of strawberry

\begin{tabular}{|c|c|c|c|c|}
\hline Var./Date & $\mathbf{D}_{\mathbf{1}}\left(\mathbf{1 5}^{\text {th }}\right.$ Oct. $)$ & $\mathbf{D}_{\mathbf{2}} \mathbf{( 1}^{\text {st }}$ Nov. $)$ & $\mathbf{D}_{\mathbf{3}}\left(\mathbf{1 5}^{\text {th }}\right.$ Nov. $)$ & D $_{\mathbf{4}} \mathbf{( 1}^{\text {st }}$ Dec. $)$ \\
\hline $\mathrm{V}_{1}$ (Sweet Charlie) & $12^{\text {th }}$ Dec. & $21^{\text {st }}$ Dec. & $11^{\text {th }}$ Jan. & $23^{\text {th }}$ Jan. \\
\hline $\mathrm{V}_{2}$ (Festival) & $7^{\text {th }}$ Dec. & $27^{\text {th }}$ Dec. & $13^{\text {th }}$ Jan. & $21^{\text {th }}$ Jan. \\
\hline $\mathrm{V}_{3}$ (Winter Dawn $)$ & $27^{\text {th }}$ Nov. & $14^{\text {th }}$ Dec. & $4^{\text {th }}$ Jan. & $17^{\text {th }}$ Jan. \\
\hline
\end{tabular}

Table.3 Effect of date of planting on end of flower initiation

\begin{tabular}{|c|c|c|c|c|}
\hline Var./Date & $\mathbf{D}_{\mathbf{1}} \mathbf{( 1 5}^{\text {th }}$ Oct.) & $\mathbf{D}_{\mathbf{2}} \mathbf{( 1}^{\text {st }}$ Nov) & D $_{\mathbf{3}}$ (15th Nov.) & D $_{\mathbf{4}}$ (1st Dec. $)$ \\
\hline V1 (Sweet Charlie) & $13^{\text {th }}$ Mar. & $17^{\text {th }}$ Mar. & $25^{\text {th }}$ Mar. & $12^{\text {th }}$ Mar. \\
\hline V2 (Festival) & $12^{\text {th }}$ Mar. & $20^{\text {th }}$ Mar. & $28^{\text {th }}$ Mar. & $10^{\text {th }}$ Mar. \\
\hline V3 (Winter Dawn) & $17^{\text {th }}$ Mar. & $18^{\text {th }}$ Mar. & $19^{\text {th }}$ Mar. & $27^{\text {th }}$ Mar. \\
\hline
\end{tabular}

Table.4 Effect of date of planting on marketable (\%) in different varieties of strawberry

\begin{tabular}{|c|c|c|c|c|c|}
\hline Var./Date & $\left.\mathbf{D}_{\mathbf{1}} \mathbf{( 1 5}^{\text {th }} \mathbf{O c t}.\right)$ & $\left.\mathbf{D}_{\mathbf{2}} \mathbf{( 1}^{\text {st }} \mathbf{N o v}.\right)$ & $\left.\mathbf{D}_{\mathbf{3}} \mathbf{( 1 5}^{\text {th }} \mathbf{N o v}.\right)$ & $\mathbf{D}_{\mathbf{4}}\left(\mathbf{1}^{\text {st }} \mathbf{D e c}.\right)$ & Mean \\
\hline $\mathrm{V}_{1}$ (Sweet Charlie) & $76.25 \%$ & $85.37 \%$ & $85.15 \%$ & $75.80 \%$ & $81.17 \%$ \\
\hline $\mathrm{V}_{2}$ (Festival) & $86.47 \%$ & $87.89 \%$ & $87.95 \%$ & $78.86 \%$ & $85.80 \%$ \\
\hline $\mathrm{V}_{3}$ (Winter Dawn) & $72.17 \%$ & $92.90 \%$ & $80.40 \%$ & $75.35 \%$ & $80.24 \%$ \\
\hline Mean & $78.10 \%$ & $88.60 \%$ & $85.03 \%$ & $76.80 \%$ & $82.19 \%$ \\
\hline \multicolumn{7}{|c|}{ C.D. at 5\% D-10.33, V-15.96 } \\
\hline
\end{tabular}

Fig.1 Weekly meteorological data during cropping season 2015-2016

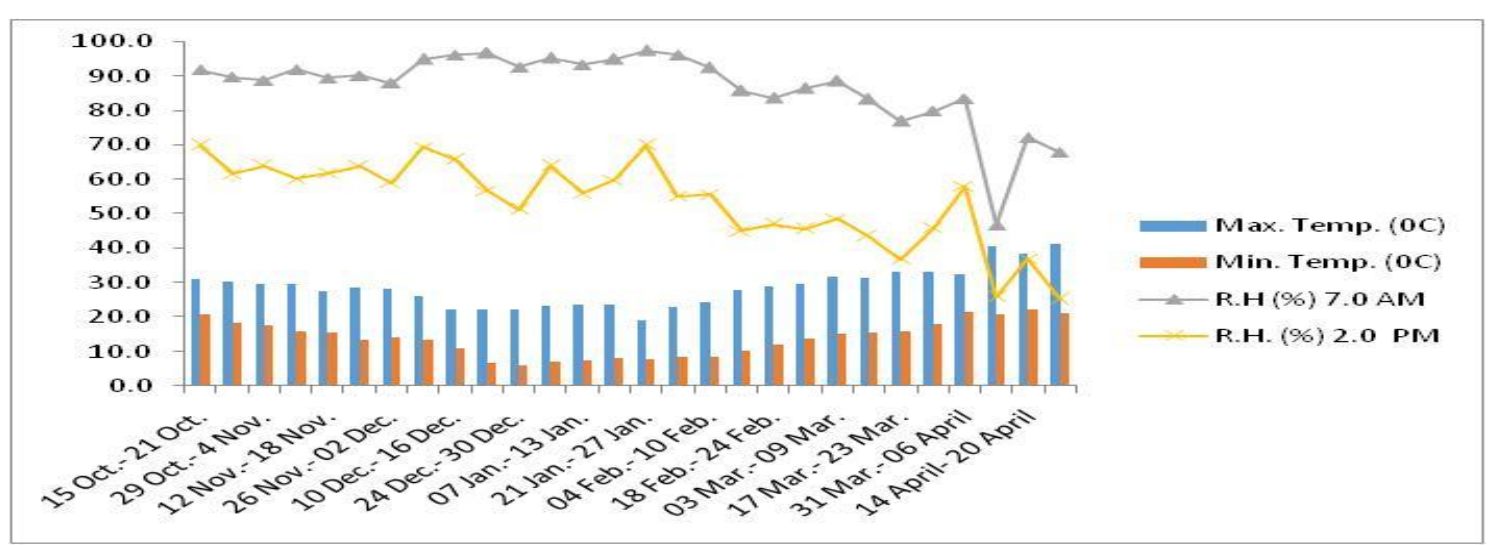


Fig.2 Plant height at 20 days interval

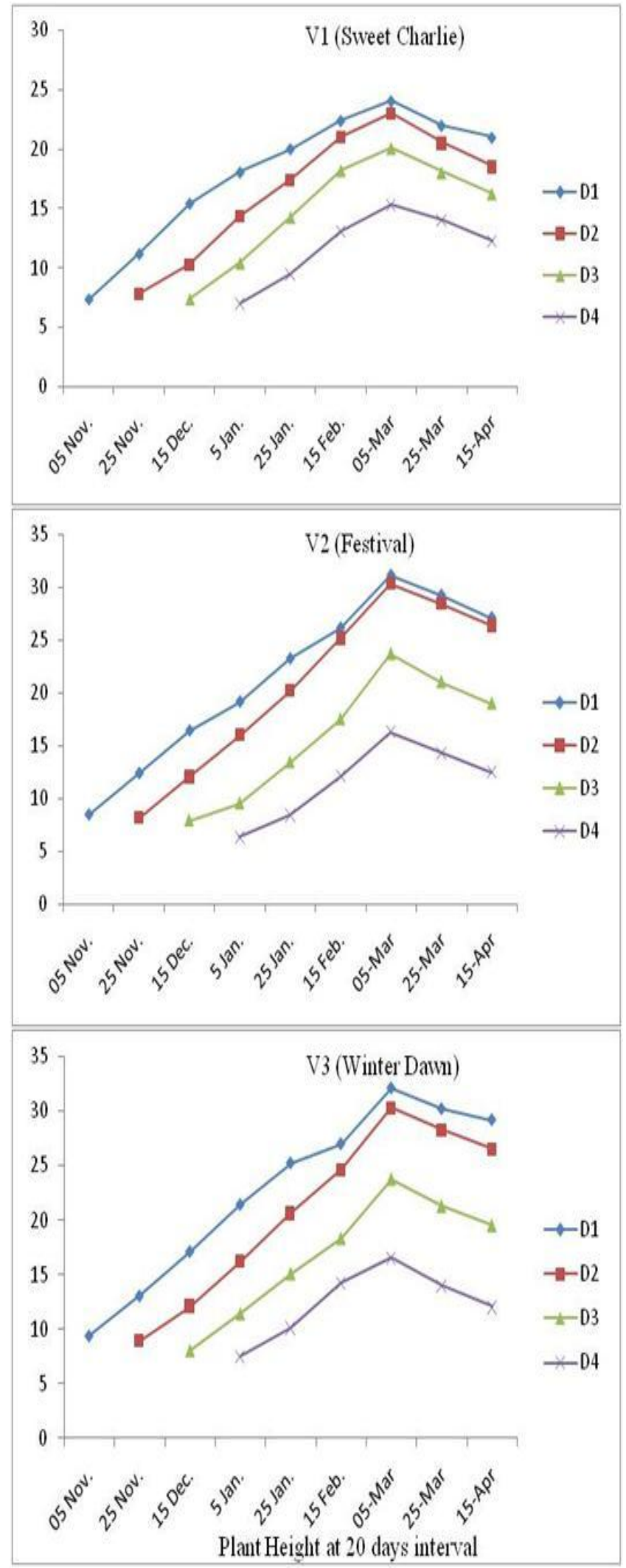

Fig.3 Plant spread at 20 days interval
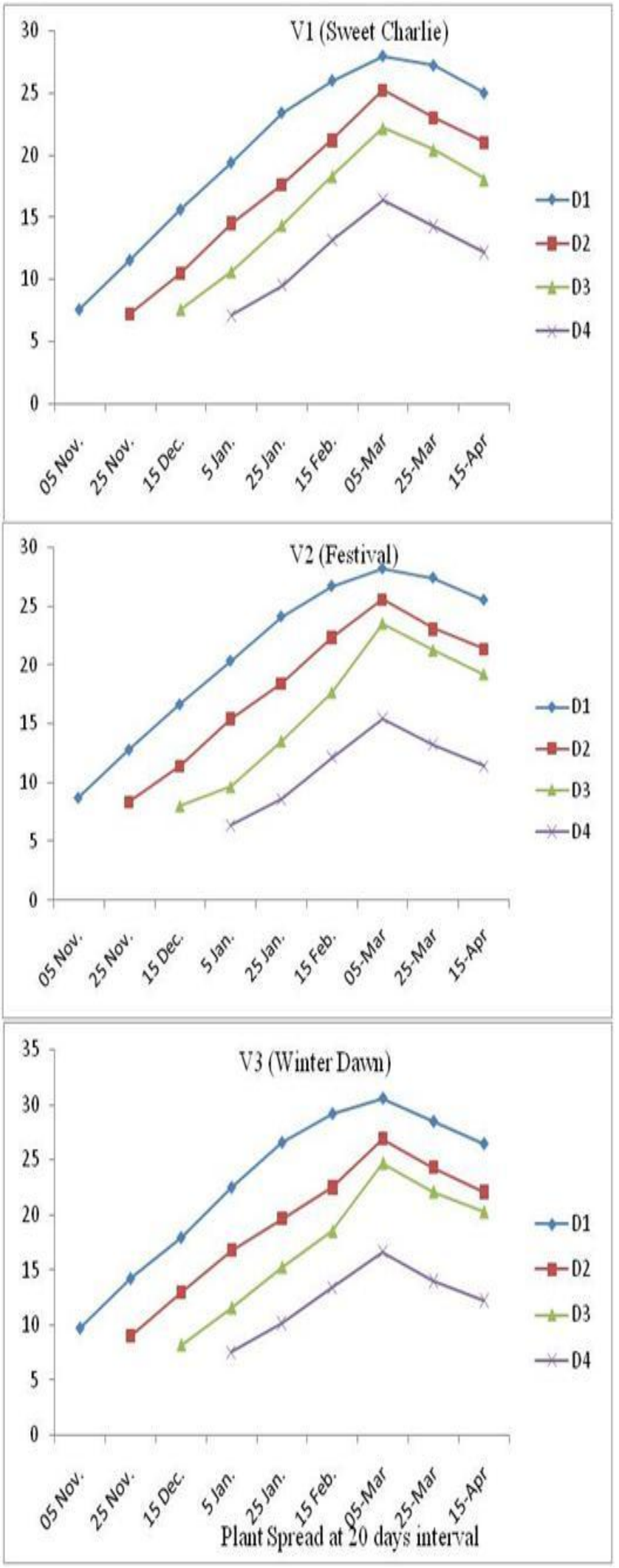
Fig.4 Number of leaves at 20 days interval
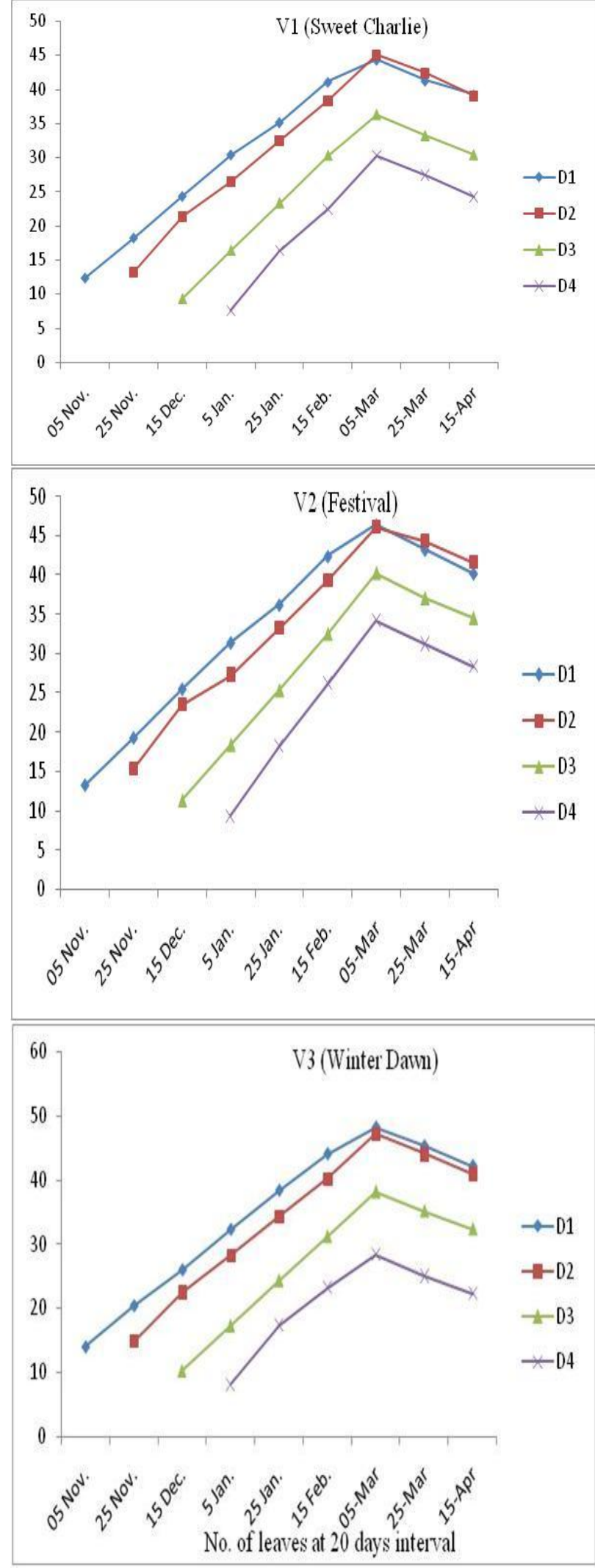

Fig.5 Number of fruits/plant harvested at 10 days interval
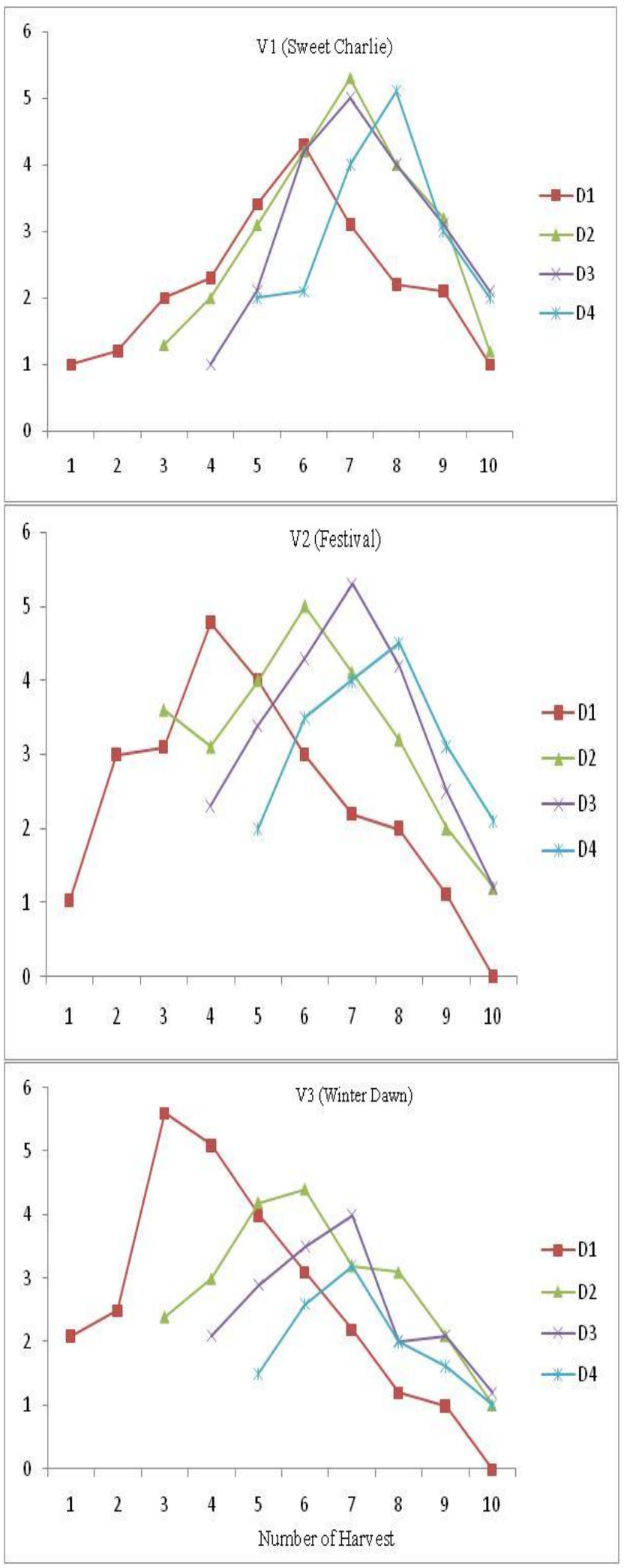
Further when flowering commenced (first fortnight of December), the day temperature was comparatively favourable for better growth and development of plants, which might have advanced both flowering and fruiting. Further when flowering commenced (first fortnight of December), the day temperature was comparatively favourable for better growth and development of plants, which might have advanced both flowering and fruiting. Plants under successive planting date had poor growth and received comparatively low temperature during plant growth which had resulted into delayed flowering and fruiting (Singh and Asrey, 2005). However, the beginning and blooming is important characteristic of flowering and fruiting behaviours because with the early blossoming cultivars there is more danger of frost damage to flowers and fruits by the late spring frosts. Similar results have been reported by Kiprijanovski and Arsov (2004).

The highest number of fruits per plant (26.80) harvested at 10 days interval was recorded on $15^{\text {th }}$ October planting in Winter Dawn and also noted on $1^{\text {st }}$ November planting in Festival i.e. 26.20 respectively. It depends on a number of factors such as cultivars, temperature and growing technology as reported by Kiprijanovski and Arsov, 2004. Findings of Asrey and Singh (2004) also in the same tune who reported varietal response to number of fruits per plant harvested in strawberry in semi-arid irrigated region of Punjab

\section{Yield parameter}

Marketable yield was also greatly influenced by variety and planting date (Table 4 ). The maximum marketable fruit percent i.e. 88.60 was recorded in $1^{\text {st }}$ November planting in variety Festival but the lowest fruit percentage was observed in $1^{\text {st }}$ December planting i.e., 76.80 percent respectively.
Better marketable yield under variety Festival was probably due to production of comparatively larger fruits with better texture, colour appearance. Variety Sweet Charlie and Festival performed well on $1^{\text {st }}$ November planting whereas, variety Winter Dawn has highest yield in $15^{\text {th }}$ October planting. These differential responses of strawberry to fruit texture, colour and quality may be attributed to variable growth attained by the plant (Arancon et al., 2004) and also due to differences in plant vigour, number and size of fruit due to different climatic condition under different planting date.

Temperature plays an important role in both variety and planting time. It affects both time and varietal responses. Hence, we concluded that the variety Winter Dawn was performed well on $15^{\text {th }}$ October planting and Festival variety performed well on $1^{\text {st }}$ November planting. So, both planting times are suitable agro climatic conditions of Bihar for successful cultivation of strawberry.

\section{References}

Arancon, N.Q., Edwards C A, Bierman P, Welch C and Metzer, J D. 2004. Influence Of vermi-composts on field strawberries: Effect on growth and yields. Biores. Tech.93: 45-53.

Asrey, R., and Singh, R. 2004. Evaluation of strawberry varieties under semi-arid irrigated region of Punjab. Ind. J. Hort. 61: 122-24.

Hassan, G. I., Godara, A. K., Kumar, J. and Huchche, A. D. 2000. Effect of different mulches on yield and quality of Grande strawberry. Indian J. Agric. Sci.70: 184-85.

Kiprijanovski, M., and Arsov T. 2004. Influence of planting time on survival, growth and bearing of the strawberries. Yaerbook of Faculty of agricultural sciences and food, Skopje, Republic of 
Macedonia, pp.101-109.

Lal, B., and Rao V K. 2010. Physicochemical characteristics of some strawberry (Fragaria X ananassa Duch.) genotypes under Gharwal region of Uttarakhand. Ind. J. Agric. Sci. 80(4): 342-4.

Palha, M. G., Campo, J. L. and Oliveira, P. B. 2012. Strawberry plant growth and dry matter partitioning as influenced by planting date and plant type in an autumn production system. Proc. XXVIII $^{\text {th }} 1 \mathrm{HC}-\quad$ International Berry Symposium. Acta Hort. 926: 463-469.

Sharma, R. R., and Sharma, V. P. 2004. Plant growth and albinism disorder in different strawberry cultivars under Delhi conditions. Indian J. Hort., 61:92-93.

Singh, A., Patel R K, De L C and Periera L S. 2008.Performance of strawberry cultivars under sub-tropics of Meghalaya. Indian Journal of Agricultural Sci., 78 (7): 1-4.

Singh, R., and Asrey, R. 2005. Growth, earliness and fruit yield of micro irrigated strawberry as affected by time of planting and mulching. Ind. $J$. Hortic., 62 (2): pp. 148-15.

\section{How to cite this article:}

Kanchan Bhamini, Ruby Rani, Md. Abu Nayyer, Md. Feza Ahmad and Afzal Ahmed. 2017. Influence of Planting Dates and Temperature on Plant Growth, Flowering and Fruiting of Strawberry in Agro Climatic Condition of Bihar, India. Int.J.Curr.Microbiol.App.Sci. 6(9): 3184-3191. doi: https://doi.org/10.20546/ijcmas.2017.609.392 